\title{
Low dose clonidine premedication accentuates the hyperglycemic response to surgery
}

\author{
[Une prémédication avec une faible dose de clonidine accentue la réaction \\ byperglycémique à la chirurgie] \\ Ralph Lattermann MD, ${ }^{*}$ Thomas Schricker MD PhD, ${ }^{*}$ Michael Georgieff MD PhD, $†$ Markus Schreiber MD $†$
}

Purpose: To investigate the influence of low dose clonidine premedication on perioperative glucose homeostasis.

Methods: Sixteen patients undergoing abdominal hysterectomy for benign uterine myoma were randomly assigned to receive either iv clonidine $\left(\mid \mu g \cdot \mathrm{kg}^{-1}\right) 30$ min before induction of general anesthesia (clonidine, $n=8$ ) or saline (control, $n=8$ ). Plasma concentrations of glucose, insulin, cortisol, epinephrine and norepinephrine were measured before, during and two hours after surgery. At the same time heart rate, mean arterial pressure and cardiac output were recorded.

Results: In both groups, glucose concentrations significantly increased during and after surgery. Intraoperative glucose plasma concentration in the clonidine group was higher than in the control group (clonidine: $6.8 \pm 0.6 \mathrm{mmol} \cdot \mathrm{L}^{-1}$ vs control: $5.7 \pm 0.8$ $\left.\mathrm{mmol} \cdot \mathrm{L}^{-1}, P<0.05\right)$. This was accompanied by a lower insulin plasma concentration (clonidine: $3.9 \pm 1.9 \mu \mathrm{U} \cdot \mathrm{mL}^{-1}$ vs control: 6.5 $\left.\pm 2.8 \mu \mathrm{U} \cdot \mathrm{mL}^{-1}, P<0.05\right)$. Heart rate, mean arterial pressure and cardiac output remained unchanged throughout the study period without any differences between the groups. While norepinephrine plasma concentrations increased in the control group only $(P<0.05)$, the plasma concentrations of epinephrine and cortisol increased in both groups $(P<0.05)$. Clonidine significantly attenuated the cortisol response as reflected by lower intra- and postoperative cortisol plasma concentrations than in the control group $(P<0.05)$.

Conclusion: Premedication with clonidine $\mid \mu g \cdot \mathrm{kg}^{-1}$ accentuates the hyperglycemic response to lower abdominal surgery caused by the decrease in insulin plasma concentrations.

Objectif : Explorer l'influence d'une prémédication avec une faible dose de clonidine sur l'homéostase périopératoire du glucose.
Méthode : Seize patientes devant subir une hystérectomie abdominale pour un myome utérin bénin ont été réparties au hasard et ont reçu de la clonidine iv $\left(I \mu g \mathrm{~kg}^{-1}\right) 30$ min avant l'induction de l'anesthésie générale (groupe clonidine, $n=8$ ) ou une solution salée (groupe témoin, $n=8$ ). Les concentrations plasmatiques de glucose, d'insuline, de cortisol, d'épinéphrine et de norépinéphrine ont été mesurées pendant l'intervention et deux heures après. Au même moment, la fréquence cardiaque, la tension artérielle moyenne et le débit cardiaque ont été enregistrés.

Résultats : Dans les deux groupes, les concentrations de glucose ont significativement augmenté pendant et après l'opération. La concentration plasmatique peropératoire dans le groupe clonidine a été plus élevée que celle du groupe témoin (clonidine : $6,8 \pm 0,6 \mathrm{mmol} \cdot \mathrm{L}^{-1}$ vs témoin : $\left.5,7 \pm 0,8 \mathrm{mmol} \cdot \mathrm{L}^{-1}, P<0,05\right)$. Ce changement s'est accompagné d'une concentration plus faible d'insuline plasmatique (clonidine : 3,9 \pm I,9 $\mu \mathrm{U} \cdot \mathrm{mL}^{-1}$ vs témoin : 6,5 $\left.\pm 2,8 \mu \mathrm{U} \cdot \mathrm{mL}^{-1}, P<0,05\right)$. La fréquence cardiaque, la tension artérielle moyenne et le débit cardiaque sont demeurés inchangés tout au long de l'étude et ce, sans différence intergroupe. Les concentrations plasmatiques de norépinéphrine ont augmenté chez les témoins seulement $(P<0.05)$ alors que celles de l'épinéphrine et du cortisol ont augmenté dans les deux groupes $(P<$ 0,05). La clonidine a diminué de façon significative la réponse du cortisol comme l'indiquent les concentrations plasmatiques peropératoires et postopératoires plus faibles que dans le groupe témoin $(P<0,05)$.

Conclusion : La prémédication avec I $\mu \mathrm{g} \cdot \mathrm{kg}^{-1}$ de clonidine augmente la réaction hyperglycémique à une hystérectomie abdominale causée par la baisse des concentrations plasmatiques d'insuline.

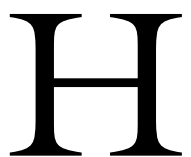

YPERGLYCEMIA, a typical feature of the metabolic response to surgery, can be profoundly influenced by the anesthetic technique. Premedication with

From the Department of Anesthesia, ${ }^{*}$ McGill University, Montreal, Quebec, Canada; and the Clinic of Anesthesiology, $†$ Ulm University Steinhövelstr Ulm, Germany.

Address correspondence to: Dr. Thomas Schricker, Department of Anesthesia McGill University, Royal Victoria Hospital, Room S5.05, 687 Pine Avenue West, Montreal, Quebec H3A 1Al, Canada. Phone: 514-842-1231, ext. 4880; Fax: 514-843-1723; E-mail: mbek@musica.mcgill.ca

Accepted for publication April 18, 2001

Revision accepted May 25, 2001. 
the central $\alpha_{2}$ agonist clonidine $4 \mu \mathrm{g} \cdot \mathrm{kg}^{-1}$ has been shown to attenuate the hyperglycemic response to neurosurgical and non-abdominal procedures, most likely a consequence of its direct sympatholytic properties. ${ }^{1,2}$ In contrast, iv clonidine administered at a lower dose caused a more pronounced increase in glucose plasma concentration during pelvic surgery. ${ }^{3}$ It was hypothesized that the hypoglycemic action of clonidine secondary to sympathoadrenergic inhibition can be overcome by a direct inhibitory effect on the $B$ cells of the pancreas and insulin secretion as shown in in vitro experiments. ${ }^{4}$

It seems that the influence of clonidine on the surgical stress response is variable depending on the dose administered and the type of surgery studied. Although the effect of clonidine premedication using doses higher than $2 \mu \mathrm{g} \cdot \mathrm{kg}^{-1}$ upon the metabolic and endocrine alterations induced by surgical trauma has been widely studied, the metabolic impact of smaller amounts received little attention. Therefore, the purpose of this study was to examine the effects of low dose iv clonidine premedication $\left(1 \mu \mathrm{g} \cdot \mathrm{kg}^{-1}\right)$ on perioperative glucose homeostasis in patients undergoing abdominal hysterectomy.

\section{Patients and methods}

\section{Patients}

The study was approved by the hospital Ethics Committee of the University of Ulm and written informed consent was obtained from all patients. Sixteen women undergoing abdominal hysterectomy for benign uterine myoma were randomly assigned to two groups. Patients received either iv clonidine 1 $\mu \mathrm{g} \cdot \mathrm{kg}^{-1}$ diluted in $15 \mathrm{~mL} 0.9 \% \mathrm{NaCl} 30 \mathrm{~min}$ before induction of general anesthesia (clonidine group, $n=8$ ) or an equivalent amount of $0.9 \% \mathrm{NaCl}$ solution (control group, $n=8$ ). The investigators, who obtained the patients' consent, were not blinded for the group assignment of the individual subject, however, were not involved in the anesthetic care of the study patients. The attending anesthesiologist, who was not aware of the patients' randomization, gave the study medication or placebo, collected the blood samples and recorded the hemodynamic variables as required by the study protocol.

\section{Anesthesia}

Premedication ( night prior to surgery and three hours before the operation. Anesthesia was induced with thiopentone 5 $\mathrm{mg} \cdot \mathrm{kg}^{-1}$ and fentanyl $1.5 \mu \mathrm{g} \cdot \mathrm{kg}^{-1}$ Orotracheal intubation was facilitated with succinylcholine $1.5 \mathrm{mg} \cdot \mathrm{kg}^{-1}$. Anesthesia was maintained with isoflurane to keep heart rate and mean arterial pressure within $20 \%$ of pre-induction values. Respiration was controlled by intermittent positive pressure ventilation at a respiratory rate of 10 breaths $\mathrm{min}^{-1}$ using $30 \%$ oxygen in nitrous oxide. The tidal volume was adjusted in order to achieve an end-tidal $\mathrm{CO}_{2}$ concentration between 35 and $40 \mathrm{mmHg}$ with capnometric control. Muscle relaxation was monitored by using the train-of-four ratio, and supplemental doses of vecuronium bromide were applied as needed for complete surgical muscle relaxation. Patients received a balanced saline solution $i v$ at $8 \mathrm{~mL} \cdot \mathrm{kg}^{-1} \cdot \mathrm{hr}^{-1}$ (TutoOP, Braun Melsungen, Germany) throughout the study period. Postoperative pain was treated with $i v$ piritramide, a synthetic opioid with a potency of approximately 0.7 compared to morphine sulfate.

\section{Study protocol}

One hour before surgery, $60 \mathrm{~min}$ after incision of the peritoneum, at the end of surgery and two hours after the operation, venous blood samples were drawn to determine the plasma concentrations of glucose, insulin, cortizol and catecholamines. All blood samples were immediately centrifuged at $4^{\circ} \mathrm{C}$ and the plasma obtained was stored at $-70^{\circ} \mathrm{C}$ until analyzed. Heart rate (HR), mean arterial pressure (MAP) and cardiac output (CO) were recorded at the same times. $\mathrm{HR}$ and MAP were measured using a three lead electrocardiography and automatic blood pressure measurement. CO was determined by thoracic bioimpedance (Non Invasive Continuous Cardiac Output Monitor NCCOM 3-R7, Bomed Medical Manufactoring Ltd., Irvine CA,USA).

\section{Measurements}

Plasma concentrations of glucose were measured by using enzymatic tests (Boehringer Mannheim $\mathrm{GmbH}$, Mannheim, Germany). The mean intra-assay and interassay coefficients of variance for glucose were $3.0 \%$ and $4.5 \%$. Insulin and cortisol were analyzed with radioimmunoassays (INS-RIA-100, Medgenix Diagnostics, Brussels, Belgium for insulin, DSL-200 SP Aktive Cortisol, Diagnostic System Laboratories, Sinsheim, Germany for cortisol). The mean intra-assay and interassay coefficients of variance were $5.6 \%$ and $8.3 \%$ for insulin and $3.0 \%$ and $7.0 \%$ for cortisol. For the analysis of epinephrine and norepinephrine $5 \mathrm{~mL}$ blood was drawn in lithium-heparinate monovettes containing 10 $\mu \mathrm{L} \cdot \mathrm{mL}^{-1}$ of a solution of $61 \mathrm{~g} \cdot \mathrm{L}^{-1}$ gluthatione and 76 $\mathrm{g} \cdot \mathrm{L}^{-1} \quad$ ethylenglykol-bis( $(\mathrm{B}$-aminoethylether)-N,Ntetraacetate (EGTA) for stabilization. Catecholamine concentrations were quantified by means of reversed phase high performance liquid chromatography 
TABLE I Patient characteristics, duration of surgery, end-tidal isoflurane concentration and total amount of piritramide

\begin{tabular}{lllllll}
\hline & $\begin{array}{l}\text { Age } \\
(\mathrm{yr})\end{array}$ & $\begin{array}{l}\text { Weight } \\
(\mathrm{kg})\end{array}$ & $\begin{array}{l}\text { Height } \\
(\mathrm{cm})\end{array}$ & $\begin{array}{l}\text { Duration of surgery } \\
(\text { min })\end{array}$ & $\begin{array}{l}\text { Isoflurane }^{l} \\
(\text { vol\% })\end{array}$ & $\begin{array}{l}\text { Piritramide }^{2} \\
(\mathrm{mg})\end{array}$ \\
\hline Control & $46 \pm 13$ & $60 \pm 10$ & $160 \pm 8$ & $137 \pm 45$ & $0.9 \pm 0.2$ & $7 \pm 4$ \\
Clonidine & $43 \pm 11$ & $61 \pm 7$ & $162 \pm 6$ & $132 \pm 74$ & $0.8 \pm 0.2$ & $9 \pm 4$ \\
\hline
\end{tabular}

Values are mean $\pm \mathrm{SD} .{ }^{1}=60$ min after peritoneal incision. ${ }^{2}=$ amount of piritramide administered within the first two hours after surgery.

TABLE II Hemodynamic variables

\begin{tabular}{|c|c|c|c|c|}
\hline & \multirow{2}{*}{ Preoperative } & \multicolumn{2}{|c|}{ Intraoperative } & \multirow[t]{2}{*}{ Postoperative } \\
\hline & & $I$ & $I I$ & \\
\hline \multicolumn{5}{|c|}{ Heart rate (beat $\cdot \min ^{-1}$ ) } \\
\hline Control & $85 \pm 13$ & $88 \pm 19$ & $82 \pm 13$ & $81 \pm 13$ \\
\hline Clonidine & $80 \pm 11$ & $86 \pm 16$ & $86 \pm 19$ & $74 \pm 12$ \\
\hline \multicolumn{5}{|c|}{ Mean arterial pressure $(\mathrm{mmHg})$} \\
\hline Control & $96 \pm 13$ & $88 \pm 10$ & $98 \pm 10$ & $99 \pm 13$ \\
\hline Clonidine & $84 \pm 9$ & $86 \pm 14$ & $87 \pm 9$ & $86 \pm 13$ \\
\hline \multicolumn{5}{|c|}{ Cardiac output $\left(\mathrm{L} \cdot \mathrm{min}^{-1}\right)$} \\
\hline Control & $6.3 \pm 1.7$ & $6.1 \pm 2.0$ & $5.8 \pm 2.0$ & $6.6 \pm 1.8$ \\
\hline Clonidine & $6.8 \pm 2.0$ & $5.4 \pm 0.9$ & $5.8 \pm 1.2$ & $7.5 \pm 1.6$ \\
\hline
\end{tabular}

Values are mean $\pm \mathrm{SD}$. I=60 min after peritoneal incision, $\mathrm{II}=$ skin closure.

TABLE III Plasma concentrations of glucose, insulin, cortisol and catecholamines before, during and after surgery

\begin{tabular}{|c|c|c|c|c|}
\hline & \multirow[t]{2}{*}{ Preoperative } & \multicolumn{2}{|l|}{ Intraoperative } & \multirow[t]{2}{*}{ Postoperative } \\
\hline & & $I$ & $I I$ & \\
\hline \multicolumn{5}{|c|}{ Glucose $\left(\mathrm{mmol} \cdot \mathrm{L}^{-1}\right)$} \\
\hline Control & $4.1 \pm 0.5$ & $5.7 \pm 0.8 \dagger$ & $6.0 \pm 1.1 \dagger$ & $7.2 \pm 1.0 \dagger$ \\
\hline Clonidine & $4.5 \pm 0.5$ & $6.8 \pm 0.6 \dagger^{*}$ & $6.9 \pm 1.1 \dagger$ & $7.8 \pm 1.4 \dagger$ \\
\hline \multicolumn{5}{|c|}{ Insulin $\left(\mu \mathrm{U} \cdot \mathrm{mL}^{-1}\right)$} \\
\hline Control & $6.4 \pm 4.4$ & $6.5 \pm 2.8$ & $7.9 \pm 4.7$ & $7.0 \pm 4.1$ \\
\hline Clonidine & $4.9 \pm 2.1$ & $3.9 \pm 1.9^{*}$ & $7.2 \pm 2.9$ & $6.5 \pm 2.6$ \\
\hline \multicolumn{5}{|c|}{ Cortisol $\left(\mu \mathrm{g} \cdot \mathrm{dL}^{-1}\right)$} \\
\hline Control & $5.5(4-19)$ & $34.0 \dagger(23-64)$ & $45.5 \dagger(23-85)$ & $49.0 \dagger(46-88)$ \\
\hline Clonidine & $9.5(7-20)$ & $26.0 \dagger^{*}(18-37)$ & $23.5 \dagger^{*}(18-39)$ & $38.5 \dagger^{*}(24-46)$ \\
\hline \multicolumn{5}{|c|}{ Epinephrine $\left(\mathrm{pg} \cdot \mathrm{mL}^{-1}\right)$} \\
\hline Control & $26 \pm 19$ & $91 \pm 46 \dagger$ & $105 \pm 59 \dagger$ & $220 \pm 160 \dagger$ \\
\hline Clonidine & $43 \pm 17$ & $152 \pm 111 \dagger$ & $146 \pm 112 \dagger$ & $232 \pm 170 \dagger$ \\
\hline \multicolumn{5}{|c|}{ Norepinephrine $\left(\mathrm{pg} \cdot \mathrm{mL}^{-1}\right)$} \\
\hline Control & $162 \pm 36$ & $404 \pm 139 \dagger$ & $371 \pm 157 \dagger$ & $477 \pm 257 \dagger$ \\
\hline Clonidine & $226 \pm 92$ & $411 \pm 270$ & $349 \pm 176$ & $383 \pm 136$ \\
\hline
\end{tabular}

Values are mean $\pm \mathrm{SD}$. Cortisol values are presented as median (range). I=60 min after peritoneal incision, II=skin closure.

$\dagger P<0.05$ vs preoperative, ${ }^{*} P<0.05$ vs control.

(HPLC-ED, Chromakon 500, Kotron, Eiching, Germany) with electrochemical detection as described earlier. ${ }^{5}$ The mean intra-assay and inter-assay coefficients of variance were $5.1 \%$ and $4.5 \%$ for epinephrine and $3.2 \%$ and $2.5 \%$ for norepinephrine, respectively.

\section{Statistics}

Calculation of power and sample size was based on the results of a previous study investigating the effect of clonidine on the endocrine response to hysterectomy. ${ }^{3}$
Using Student t- test and considering an expected mean difference in glucose plasma concentration of $15 \%$ between the groups (power $80 \%,=5 \%$ ), a total of eight patients was calculated to be sufficient.

Differences between the groups were analyzed using Student's t- test. Within the groups comparison of variables was made by ANOVA for repeated measures followed by Dunnet's test. Cortisol values were not distributed normally and are presented as median (range). Cortisol data were analyzed using Friedman's 
two-way ANOVA and the Kruskal-Wallis test for differences between groups. A probability of less than 0.05 was accepted as significant. Data are presented as mean \pm SD

\section{Results}

The groups were similar in mean age, body weight and height (Table I). The duration of surgery, the intraoperative end-tidal isoflurane concentration and the amount of piritramide administered for postoperative pain treatment were comparable in both groups. Estimated blood loss never exceeded $300 \mathrm{~mL}$ and no patient received blood transfusion.

In both groups, HR, MAP and $\mathrm{CO}$ remained unchanged throughout the study without significant differences between the groups (Table II). Plasma glucose concentration increased in both groups during surgery and remained elevated throughout the study period (Table III). Plasma glucose concentration was higher in the clonidine group than in the control group $60 \mathrm{~min}$ after peritoneal incision. This was accompanied by a lower plasma insulin concentration. In both groups, the plasma concentrations of cortisol and epinephrine increased during surgery and remained elevated thereafter. However, in patients receiving clonidine the intra- and postoperative cortisol plasma concentration was lower than in the control group. The plasma concentration of norepinephrine increased during and after the operation in the control group only.

\section{Discussion}

The hyperglycemic response to surgery has been mainly ascribed to the stimulation of sympathoadrenergic and pituitary pathways resulting in increased plasma concentrations of catecholamines and cortisol. Due to its sympatholytic action, clonidine suppresses parts of the endocrine surgical stress response with potential impact on perioperative glucose homeostasis. ${ }^{6,7}$ Premedication with clonidine, administered either orally or intravenously at doses of 4 to $7 \mu \mathrm{g} \cdot \mathrm{kg}^{-1}$, has been reported to blunt increases in catecholamine plasma concentrations during major surgery. ${ }^{1,8,9}$ In the present study, low dose $i v$ clonidine premedication $\left(1 \mu \mathrm{g} \cdot \mathrm{kg}^{-1}\right)$ did not significantly affect the sympathoadrenergic and hemodynamic responses to surgery indicating that the sympatholytic effect of clonidine is dose-dependent. Furthermore clonidine premedication has been shown to attenuate the cortisol and hyperglycemic responses to surgery, particularly during neurosurgical procedures and in children undergoing minor surgery. ${ }^{1,2}$ In contrast, clonidine administration of $3 \mu \mathrm{g} \cdot \mathrm{kg}^{-1}$ caused a more pronounced increase in glucose plasma concen- tration during abdominal hysterectomy without affecting pituitary hormone secretion or plasma cortisol. ${ }^{3}$ Although insulin plasma concentrations were not measured, the hyperglycemic action of clonidine observed in that study was attributed to the inhibitory effect of clonidine upon the $\beta$ cells of the pancreas and decreased insulin release. In the present study, low dose clonidine premedication was also associated with a higher plasma glucose concentration compared with the control group $60 \mathrm{~min}$ after peritoneal incision, i.e., 90 min after iv administration, when the maximum effect is expected. ${ }^{10}$ In addition, the intraoperative insulin plasma concentration was significantly lower in patients receiving clonidine. This finding is in agreement with previous in vivo and in vitro observations showing a direct suppressory influence of clonidine on the pancreatic insulin secretion. ${ }^{4,11}$ However, other mechanisms have also been proposed to be responsible for the hyperglycemic action of clonidine, such as increased gluconeogenesis or glycogenolysis, mediated via stimulation of $\alpha_{2}$ adrenergic receptors located in the central nervous system. ${ }^{12}$

The attenuation of the cortisol response by clonidine in our study is in contrast to the results of previous investigations reporting no modifying effect of clonidine administered at a higher dose ( 2 or 3 $\mu \mathrm{g} \cdot \mathrm{kg}^{-1}$ ) in unpremedicated patients undergoing abdominal hysterectomy. ${ }^{3,13}$ It has to be noted, however, that all patients entering the present study protocol received oral premedication with benzodiazepines ( $20 \mathrm{mg}$ chlorazepate) the night prior to surgery and three hours before the operation, which per se affects perioperative ACTH and cortisol plasma concentrations. ${ }^{14}$

We conclude that premedication with clonidine administered at a dose insufficient to inhibit the surgery induced stimulation of sympathoadrenergic pathways, accentuates the hyperglycemic response to surgery most likely mediated through its inhibitory effect on insulin secretion. We further hypothesize that the hyperglycemic action of low dose clonidine is overlaid by the suppression of the sympathoadrenergic response to surgery if larger doses are administered.

\section{Acknowledgement}

The excellent technical assistance of R. Engelhardt is gratefully acknowledged.

\section{References}

1 Gaumann DM, Tssonyi E, Rivest RW, Fathi M,

Reverdin AF. Cardiovascular and endocrine effects of clonidine premedication in neurosurgical patients. Can J Anaesth 1991; 38: 837-43. 
2 Nishina K, Mikawa K, Maekawa N, Shiga M, Obara $H$. Effects of oral clonidine premedication on plasma glucose and lipid homeostasis associated with exogenous glucose infusion in children. Anesthesiology 1998; 88: 922-7.

3 Lyons FM, Bew S, Sheeran P, Hall GM. Effects of clonidine on the pituitary hormonal response to pelvic surgery. Br J Anaesth 1997; 78: 134-7.

4 Hirose H, Seto $\Upsilon$, Maruyama H, Dan K, Nakamura K, Saruta T. Effects of $\alpha_{2}$-adrenergic agonism, imidazolines, and G-protein on insulin secretion in $\beta$ cells. Metabolism 1997; 46: 1146-9.

5 Dirks B, Vorwalter C, Grünert A, Abnefeld FW. Basal plasma-catecholamine-level determination using HPLC-ED and different sample cleanup techniques. Chromatographia 1988; 25: 223-9.

6 Dorman T, Clarkson K, Rosenfeld BA, Shanboltz C, Lipsett PA, Breslow MJ. Effects of clonidine on prolonged postoperative sympathetic response. Crit Care Med 1997; 25: 1147-52.

7 Hayashi Y, Maze M. Alpha ${ }_{2}$ adrenoceptor agonists and anaesthesia. Br J Anaesth 1993; 71: 108-18.

8 Quintin L, Roudot F, Roux C, et al. Effect of clonidine on the circulation and vasoactive hormones after aortic surgery. Br J Anaesth 1991; 66: 108-15.

9 Flacke JW, Bloor BC, Flacke WE, et al. Reduced narcot ic requirement by clonidine with improved hemodynamic and adrenergic stability in patients undergoing coronary bypass surgery. Anesthesiology 1987; 67: $11-9$.

10 Lowenthal DT, Matzek KM, MacGregor TR. Clinical pharmacokinetics of clonidine. Clin Pharmacokinet 1988; 14: 287-310.

11 Metz SA, Halter JB, Robertson RP. Induction of defective insulin secretion and impaired glucose tolerance by clonidine. Selective stimulation of metabolic alphaadrenergic pathways. Diabetes 1978; 27: 554-62.

12 DiTullio NW, Cieslinski L, Matthews WD, Storer B. Mechanisms involved in the hyperglycemic response induced by clonidine and other alpha- 2 adrenoceptor agonists. J Pharmacol Exp Ther 1984; 228: 168-73.

$13 \mathrm{Kim} \mathrm{MH,} \mathrm{Habn} \mathrm{TH}$. The effect of clonidine pretreatment on the perioperative proinflammatory cytokines, cortisol, and ACTH responses in patients undergoing total abdominal hysterectomy. Anesth Analg 2000; 90 1441-4.

14 Crozier TA, Beck D, Schlaeger M, Wuttke W, Kettler D. Endocrinological changes following etomidate, midazolam, or methohexital for minor surgery. Anesthesiolgy 1987; 66: 628-35. 